\title{
Antimalarial chloroquine metamorphosed into antiviral agent against HIV with four modes of actions
}

\author{
M Chandramohan ${ }^{1 *}$, P Selvam², SC Vivekananthan ${ }^{3}$, D Sivakumar $^{1}$, E De Clercq ${ }^{4}$ \\ From First International Science Symposium on HIV and Infectious Diseases (HIV SCIENCE 2012) \\ Chennai, India. 20-22 January 2012
}

\section{Background}

To identify an economical and effective antiviral agent we are nurturing chloroquine (CQ) which is an antiviral agent with multimodal and immune modalatory actions. Earlier studies have reported inhibition of HIV by CQ through its anti-integrase activity and also had elucidated that CQ inhibits HIV by inhibiting glycosylation of envelope glycoprotein. It had also been shown that CQ blocked Tumor-Necrosis-Factor (TNF-) alpha and Interleukin-6(IL-6); production and interferes with HIV replication.

\section{Method}

In vitro assay of anti HIV activity of CQ in MT4-cells and clinical study.

\section{Results}

We observed Inhibitory Concentration (IC50) $7.19 \mathrm{ug} / \mathrm{ml}$ and Cytotoxic-Concentration (CC50) $>35.43$ and the maximum protection noted was 90; a laudable observation. Results on hand; we launched a preliminary study of giving CQ at 2 tables per day as add-on drug along with other antiretroviral agents to $6 \mathrm{HIV}$ patients proved by ELISA and Western blot; age ranged between 6 and 48. We have observed CD4 and CD8 cells count improved by $20 \%$ to $35 \%$ but their sustaining effects couldn't be assessed because two patients died due to overwhelming intercurrent infection and four patients had good improvement for 2-3 yr and lost for further follow up. This report of ours is next to first Indian report.

\footnotetext{
* Correspondence: kamaraj_liver_hospital@yahoo.com

'Kamarajar Jaundice, Liver Hospital \& Research Centre, Madurai-625001, Tamil Nadu, India

Full list of author information is available at the end of the article
}

\section{Conclusion}

We could ascertain that this add-on drug CQ had been tolerated well and major side effects were not observed and with good anti HIV action.

\section{Author details \\ 'Kamarajar Jaundice, Liver Hospital \& Research Centre, Madurai-625001, Tamil Nadu, India. ${ }^{2}$ Devaki Amma Memorial College of Pharmacy, Chelembra, Malapuram-673436, Kerala, India. ${ }^{3}$ Madurai Medical College, Madurai-625020, India. ${ }^{4}$ Rega Institute of Medical Research, Katholieke University, B-3000, Leuvan, Belgium.}

Published: 4 May 2012

doi:10.1186/1471-2334-12-S1-O21

Cite this article as: Chandramohan et al: Antimalarial chloroquine metamorphosed into antiviral agent against HIV with four modes of actions. BMC Infectious Diseases 2012 12(Suppl 1):021.

Submit your next manuscript to BioMed Central and take full advantage of:

- Convenient online submission

- Thorough peer review

- No space constraints or color figure charges

- Immediate publication on acceptance

- Inclusion in PubMed, CAS, Scopus and Google Scholar

- Research which is freely available for redistribution

\section{() Biomed Central}

